PHILOSOPHY

\title{
КУЛЬТУРА ПОЧАТКУ НОВОГО ТИСЯЧОЛТТТЯ: УКРАЇНСЬКИЙ ДОСВІД
}

Тетяна Гуменюк, доктор філософських наук, професор, Київський національний університет культури і мистеитв, Київ, Україна

DOI: https://doi.org/10.31435/rsglobal_conf/25122020/7313

\begin{abstract}
It is characterized a wide range of inter-subject studies of the concept of trauma and involved theoretical tools of multi- and inter-subject texts "trauma studies" for analyze of various types of narrative about the collective traumatic experience of Ukrainian society at the beginning of 20th century. The sensitivity of society to the topic of violence, its theorization and detailed categorization, or vice versa - refusal, the impossibility of the last grows with the deepening of the modern tragic experience of mankind. Simultaneously as political rhetoric is becoming more biopolitical, a new conceptual paradigm is built around the concept of trauma, according to which the society and politics, religion and law, medicine and psychoanalysis, science and art can be in a new relationship. The long-time impact of a traumatic experience on an individual is close to the long-time effect of national trauma on the collective consciousness, which creates a feeling of fear and vulnerability at both individual and collective levels: for both the individual and the team, the event becomes a "turning point" dividing life into "before and after". One of the important problems in the formation of modern Ukrainian society is an absence of a unifying myth that would guide the current contradictory, sometimes tragic transgressive processes. For example, in different regions, the social groups rather arbitrarily interpret the events of the Second World War, the Soviet past of the country, the modern movement to the European iteration and many other phenomena of public life. Such inconsistency is generally inherent in the Ukrainian mentality, it reflects the consciousness of Ukrainian society experienced the influence of traumatic processes determining the present and affect the future of the country. Only by impartially analyzing these events, one can understand and explain how to create modern effective forms of social being. Due to the Chernobyl disaster, Ukraine turned out to be a deeply traumatized social space that signals the world about a new state: about entering the zone of a new culture of humanity of the third millennium.
\end{abstract}

Keywords: post-Soviet culture, concept of trauma, discursive analysis of traumatic experience, cultural/ collective memory.

Вступ. Глобальні трансформації в сучасному світі зазнають впливу процесів, що відбуваються на пострадянському просторі, адже вони сформували унікальний тип культури, який дослідники визначають як продукт травми, завданої тривалими процесами внутрішньої колонізації ментальності народу.

В історії України, зокрема протягом XX і XXI століть, відбулось багато трагічних подій, які стали джерелом травмуючого досвіду: Перша світова війна, Громадянська війна, колективізація, депортації, Голодомор 1932-33 років., сталінський терор 30-х і повоєнних років, Друга світова війна, голод 1947 року, розпад Радянського Союзу, Чорнобильська катастрофа, Майдан, анексія Криму, війна на Донбасі. Важливо розуміти характер породжених ними культурних, соціальних, психологічних колективних та індивідуальних змін і перетворень, а також стратегій роботи 3 таким досвідом, зокрема й психолінгвістичних, щоб надалі більш успішно долати його негативні наслідки. Теоретичний дискурс щодо подій, які спричинили колективу травму, є одним з елементів тієї культурної рамки, що наділяє травму мовою і надає змогу іiі суб'єкту переборювати впливи і наслідки пережитого. Крім того, це, як мінімум, привертає увагу соціуму до набутого трагічного досвіду, який завдає глибоких соціальних $\mathrm{i}$ психічних травм, потребує опрацювання й осмислення. Відсутність або недостатність відповідної аналітики загрожує тим, що травма набуває хронічного характеру і транслюється наступним поколінням. Отже, тема статті видається актуальною, іiі мета - охарактеризувати досить широке коло міждисциплінарних досліджень концепту травми, проаналізувати становлення різних типів наративу про колективний травмуючий досвід, якого набуло українське суспільство на початку XXI століття, залучаючи для цього теоретичний інструментарій мульти- й міждисциплінарних текстів «trauma studies».

Методи і методики дослідження. Здійснений аналіз міждисциплінарних досліджень концепту травми, залучення теоретичного інструментарію мульти- й міждисциплінарних 
текстів «trauma studies» надав можливість розкрити сутність різних типів наративу про колективний травмуючий досвід, якого набуло українське суспільство на початку XXI століття.

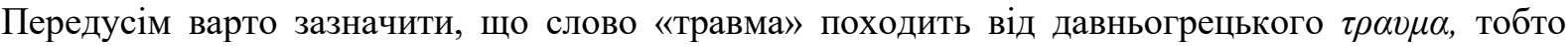
«рана» (A Genealogy Publisher: University of Chicago Press; 1 edition. 2000) i, на думку більшості дослідників, концепт «травматичності» $є$ парадигматичною характеристикою не лише історії і культури XX, а й початку XXI століття. Тому чутливість суспільства до теми насилля, теоретизація і детальна категоризація цих явищ або ж навпаки - відмова, неможливість останньої (у випадках крайнього насилля, що руйнує будь-які категорії), зростають 3 поглибленням сучасного травмуючого досвіду людства. Паралельно до того, як політична риторика стає все більш біополітичною, щодо поняття травми вибудовується нова концептуальна парадигма, згідно з якою суспільство і політика, релігія і право, медицина i психоаналіз, наука і мистецтво можуть перебувати у новому взаємозв'язку.

Результати і дискусії. За основу «магістрального концепту» нашої статті взято твердження Тамари Гундорової про необхідність: «...проговорити i пропрацювати травматичні місця української культури початку XXI століття - постколоніальний ressentiment, розрив генерацій i пам'ять про минуле в сучасному пострадянському романі (i в художній культурі загалом, додамо ми - Т.Г), розрив високої і популярної культури, нове розуміння класики, кітчезацію як спосіб рецепції травматичного досвіду, а також Чорнобиль - подію, яка значною мірою визначила й оформила теперішнє мислення в Україні» (Гундорова, 2013: 20). Незаперечність цієї думки підтверджує й унікальне художнє явище 2019 року, яке потрясло весь світ - американський мінісеріал про катастрофу на Чорнобильскій AEC. I це сталося не завдяки участі якихось знаменитостей чи гучним рекламним кампаніям і грандіозним промоторам. Цей фільм змушує глядача відчути жах, відчай, безпомічність, розгубленість і трагічну безвихідь людей, які пережили цю трагедію. Приховуючи реальний стан речей, всі, безпосередньо причетні до неї, тотально фабрикують брехню. Політики, чиновники, працівники станції (!, навіть у критичному стані радіаційного отруєння) продукують велику брехню, щоб приховати страшні масштаби катастрофи.

Фільм «Чорнобиль» не сприймається як звинувачення радянській системі чи кампанія проти застосування ядерної енергетики. Вся увага в ньому зосереджена на рисі, спільній для всіх людей - брехні і на тому, чим це обертається не лише у великих масштабах геополітики, а на рівні особистих відносин (і це найважливіше!). «Чорнобиль» відрізняється тим, що він торкається загальнолюдських начал... У цьому фільмі йдеться не лише про Чорнобиль, ... а й про нас, - пише у своєму відгуку на серіал Ерлінгур Ейнарссон (https://www.gamesradar.com/chernobyl-hbo-review/)

Суголосними цим роздумам $є$ дослідження вчених світу, розпочаті у 70 -ті роки $\mathrm{XX}$ століття i спрямовані на розробку так званого Посттратравматичного Стресового розладу. Дослідники виявляли і порівнювали зв'язки між психологічними реакціями тих, хто пройшов В'єтнамську війну, хто вижив після бомбардування Хіросіми і нацистських тортур, пережив Голокост або наслідки рабства i сегрегації серед представників афроамериканської ідентичності. Внаслідок цього було вироблено нову, головну для нашого часу категорію - «the survivor»: «той, хто вижив», «потерпілий», «жертва». Політики ідентичності сприяли іiі поширенню (Luckhurst R., 2008: 62).

Роберт Джей Ліфтон - один із провідних дослідників питань переоцінювання й розширення дискурсу щодо концепту травми в контексті сучасної культури. Зокрема, у своїх книгах «Технологія «промивання мозку»: Психологія тоталітаризму» ${ }^{1}$ та «Смерть у житті: ті, хто вижив після Хіросіми» Р. Ліфтон пише про війни, соціальні й екологічні катастрофи як про раптовий і абсолютний зсув у звичному житті, як немислиме зіткнення зі смертю. Фактично, автор намагається поширити внутрішні страждання потерпілих людей на весь зовнішній світ. Стверджуючи, що деструктивний для всього світу потенціал цих катаклізмів означає, що «ми всі належимо до тих, хто уцілів після Хіросіми», і додамо: після Голокосту, після колоніалізму, після тоталітаризму, після Чорнобиля, після Майдану, після «війни» як найбільших колективних, індивідуальних і, зрештою, національних травм.

\footnotetext{
1 Лифтон Р. Технология «промывки мозгов»: Психология тоталитаризма. - СПб.: Прайм-Еврознак, 2005.; Перше видання Robert Jay Lifton Lifton, Robert Jay. (1926- ) Thought reform and the psychology of totalism: the study of brainwashing in China. Bibliography: p. Includes index 1. Brainwashing - China. 2. Communism China ISBN 08078-4253-2 The University of North Carolina Press, W. W. Norton \& Company, New York, 1961). Robert Jay Lifton Death in Life: Survivors of Hiroshima. New York, 1968.
} 
Тут важливо зазначити, що тривалий вплив травматичного досвіду на індивіда подібний до тривалого тиску національної травми на колективну свідомість, що породжує відчуття страху і вразливості як на індивідуальному, так і на колективному рівнях: як для індивіда, так i для колективу подія стає «поворотним моментом», що розмежовує життя на «до» $\mathrm{i}$ «після».

Важливою для розгляду порушеної проблеми є теорія національної травми Артура Ніла («Національна травма і колективна пам'ять: головні події в американському столітті»), згідно 3 якою вирішальними факторами для перетворення події на національну травму є ії відхилення від «норми», від звичного стану речей, призводячи до радикальних змін у соціальній тканині настільки, що «це торкається всіх основних підгруп населення» (Neal A., 2005: 10). При цьому криза, що актуалізує національну травму може бути гострою, спричиненою конкретним агресивним актом (як вбивство президента А. Лінкольна, японська атака на Перл-Гарбор) або ж хронічною, з тривалою інтенсивністю (Велика депресія чи В'єтнамська війна).

Ці роздуми мають безпосередне відношення до ситуації, яка склалася в Україні. Зокрема, Т. Гундорова відзначає, що українське суспільство перебуває у довготривалому процесі виходу зі стану поневолення - політичного, соціального, економічного i, зрештою, ментального. Дослідниця характеризує культуру України як продукт травми і називає ії транзитною. Як не дивно, але саме це слово набуває особливої ваги сьогодні, коли з 1липня 2019 року відновлено транзит українських товарів через територію Росії в інші країни. Здавалося б, питання суто економічне, однак воно фіксує й увиразнює певні духовні пріоритети часу нинішнього - його загальноісторичну й загальнокультурну «драматургію». Цей факт, характеризуючи інші тенденції, може, й не такі вже інші, зважаючи на взаємопов'язаність всіх процесів у культурі, потребує розгляду того, що зараз відбувається між Україною та іншими країнами. Українське суспільство внаслідок трагічних подій у своїй історії кінця XX - початку XXI століть переживає перехід (транзит! - лат. прийменник тrans, - «крізь», «через» та дієслово «trans+ire» «проходити») у новий стан буття культури. Цей процес тривалий і супроводжується багатьма трагічними подіями як для окремої особистості, так і для народу загалом.

До речі, комунікативні патерни, властиві індивідуальній травмі, відрізняються від тих, які притаманні національній, колективній травмі: якщо індивіди неохоче передають негативну чи тривожну інформацію, то травматична подія національного масштабу швидко поширюється, зазнає масового переживання, внаслідок якого виникає ефект взаємного «тяжіння»: індивіди об'єднуються у певні групи, щоб мати можливість певним чином зреагувати, відповісти на трагедію. До того ж, якщо індивідуальні реакції на травматичний досвід можуть бути різними, часом навіть протилежними, то «...колективні відповіді схильні до стандартизації у процесі розробки міфів і легенд, спрямованих на те, щоб означити моральні межі суспільства» (Neal A., 2005: 20). У такій спосіб здійснюється реформування суспільства як моральної спільноти («moral community») і створюються сакральні символи, здатні формувати національну ідентичність.

Одну 3 важливих проблем на шляху формування сучасного українського суспільства становить відсутність об'єднуючого міфу, який би спрямовував нинішні суперечливі, часом трагічні трансгресивні процеси в суспільстві. Скажімо, в різних регіонах, соціальних групах зазнають досить довільної інтерпретації події Другої світової війни, радянське минуле країни, сучасний рух до європейської ітерації та багато інших явищ суспільного життя. Така суперечливість загалом притаманна українській ментальності, вона відбиває стан української свідомості, яка зазнала впливу травматичних процесів, що визначають сьогодення і впливають на майбутне країни. Водночас, ці тенденції свідчать про схильність і здатність громадськості долати межі конфлікту ідеалів. Кризові ситуації стають своєрідними вікнами-розломами у вільний світ. Тільки неупереджено аналізуючи ці події, можна зрозуміти і пояснити, як створити сучасні ефективні форми суспільного буття.

Унаслідок Чорнобильської катастрофи Україна постала глибоко травмованим соціальним простором, який сигналізував світові про новий стан: входження в зону нової культури людства третього тисячоліття. Як зауважує А. Ніл «...травма часто вивільняє соціальну систему: підважуючи старий порядок, вона виявляє нові можливості та інновації, коли сам факт появи підривної події може свідчити про неефективність соціальної системи» (Neal A., 2005: 18). Відтворення цієї трагедії на екрані справило враження дивовижної сили сьогодні Україна сприймається у світі як унікальний простір, у якому зосереджено колективний травматичний досвід, важливий для всього людства як застереження і попередження.

Американський телефільм «Чорнобиль», за версією IMDB, визнано найпопулярнішим серіалом всіх часів (!), він викликає дискусії, збуджує пристрасні реакції. Зону відчуження нині 
масово прагнуть відвідати туристи й журналісти. Однак ті трагічні події мають не лише катастрофічні техногенні наслідки - не меншим виявилося онтологічне потрясіння: сформувалась нова екологія культури, яка містить дискурс колективної травми людства, яке живе після «доторку смерті».

Усвідомлюючи, що будь-яка аналогія досить умовна, все ж нагадаємо у цьому контексті про пожежу, яка сталась у квітні 2019 року в соборі Нотр-Дам-де-Парі. Відомо, що 1831 року Віктор Гюго написав цей однойменний роман, щоб привернути увагу громадськості до визначної пам'ятки національної архітектури, яка настільки постраждала в роки Великої французької революції, що могла бути втраченою назавжди. Але видання роману, у передмові до якого В. Гюго писав: «Одна 3 головних цілей моїх - надихнути націю любов’ю до нашої архітектури»»", - спонукало громадськість до відбудови собору. Після пожежі 2019 року таку місію взяли на себе, окрім ЗМІ та Інтернет, діячі культури, мистецтва Франції і світу.

Щодо серіалу «Чорнобиль», то він знову привернув увагу до проблеми «повернення пам'яті». Автор сценарію Крег Мейзин зібрав книги про Чорнобиль, які допомогли йому в роботі над фільмом. Серед них багато й українських видань, зокрема: «Чорнобиль: документальна повість» («Дніпро», 1989) Юрій Щербака, «Чорнобильская тетрадь» («Дніпро», 1990) Григорія Медвєдєва, «Оформляндія, або Прогулянка в зону» (Нора-Друк, 2015) Маркіяна Камиша, «Чонобильське досьє КГБ». (Составители: Отраслевой государственний архив СБУ, Институт истории НАНУ, Украинский институт национальной памяти, 2109) та ін. Принциповим для авторів і упорядників цих книг є усвідомлення того, що постраждалі не просто пам'ятають про минуле, а й сьогодні живуть цією подією, тому вона завжди актуалізована в теперішньому часі. «Травмовані...самі перетворюються на симптом історії, якою вони не в змозі цілковито оволодіти» (Caruth C. 1995: 5). Таким чином травма тісно пов'язується 3 проблемою правди або з тим, що називають «кризою правди», відповідно порушуючи питання: як ми у наш час можемо мати доступ до свого історичного досвіду. Тому не існує єдиного підходу до слухання (listening), вслухання у травматичний досвід та в історії про нього. Їх винятковість вимагає якнайрізноманітніших рефлексій у пихоаналітиці й психолінгвістиці, у філософії й культурології, у політології й історії, як і в мистецтві загалом. Потреба комплексного осмислення породжена свосрідністю самої події як виключного, трагічного досвіду, який виходить за межі людського розуміння.

Українське мистецтво (nota bene! - тут неминучі паралелі з романом французького класика) привертає увагу до України, іiі історії і сучасних проблем завдяки художньому відтворенню чорнобильської трагедії (інших трагедій в сучасній і постсучасній історії) в ії «неіндивідуальності». Засобами мистецтва розкривається суворе, безкомпромісне розуміння явищ і подій, які переживає Україна, вступаючи в нову, постімперську, пострадянську фазу своєї історії. Суспільство болісно переживає тривалий процес виходу з полону багатовікової колонізації ментальності. Нова генерація українських митців творить сучасний національний простір, сповнений соціокультурної рефлексії, спрямованої на осмислення «свого» $\mathrm{i}$ «чужого», центру i периферії, домінантного і підлеглого, індивідуального й соціального, моно- i полікультурного, автентичного і глобалізованого, засвідчуючи цим стан культури третього тисячоліття: входження у світ «sub specie»*1 нових моральних і технологічних викликів.

3 часу чорнобильської катастрофи в Україні відбулося так багато значних історичних подій і соціокультурних зсувів, що нині можна говорити про зовсім іншу реальність, ніж та, 3 якою асоціюють кінець ХХ століття як час падіння тоталітарних режимів.

Процеси, пережиті українським суспільством, починаючи з кінця 2013 року, дають змогу говорити про їх колективний характер, адже вони спричинили тектонічні зсуви в новітній історії України: Революція Гідності, розстріл учасників Майдану, згодом - анексія Криму, військова агресія в Донбасі, проголошення ДНР і ЛНР, економічна і політична криза, яка викликала нове культурне піднесення, що виявилось у волевиявленні народу на президентських і парламентських виборах 2019 року. Про це досить полемічно, з болем усвідомлюючи важкий політичний досвід Майдану, пише історик А. Плахонін: «Минулі вибори поставили крапку в добі самомилування, що тривала п’ять років, які ми називали гідністю.» (А. Плахонін, 2019: 26).

Унікальність дослідження Т. Гундорової «Транзитна культура» полягає в тому, що, незважаючи на швидкоплинні й вкрай стрімкі соціополітичні й культурні зміни, їі ідеї не

\footnotetext{
1 * «sub specie» - лат. - 3 точки зору («sub specie aeternitatis» - «з точки зору вічності» - так повністю звучить відомий латинський вислів)
} 
застарівають, а набувають ще більшої актуальності, сприяють зрозумінню ситуації, в якій опинилась Україна внаслідок другого Майдану і тривалої війни на Донбасі. Особливо цінним для осмислення нинішньої української реальності мають зауваження дослідниці щодо «ресентименту» як чинника формування постколоніальної і посттоталітарної суспільної (суб’єктивної) свідомості. Незважаючи на буквальне значення цього поняття (франц. ressentiment - обурення, озлобленість), воно більш складне й суперечливе за своїм смислом. Феномен ресентименту виникає в ситуації надзвичайного напруження між набутим почуттям самоповаги i, водночас, ненавистю до всього ворожого, що усвідомлюється як причина й джерело ущербності, втрат, безсилля, зрештою, - неповноцінності. Такий стан «...і є тією критичною інстанцією, де афекти набувають форми ресентименту. Розрядка веде або до патології, або ж перетворюється на скомпліковану, але продуктивну культурну терапію» (Гундорова, 2013: 51).

Зважаючи на події, які переживає сьогодні українське суспільство, досвід Майдану вписується у значно ширший контекст посткомуністичної травми, більше того - у дискурсивне поле trauma studies, що для більшості дослідників $є$ взагалі парадигмальною характеристикою культури кінця XX - початку XXI століть. Так, Шошана Фелман наголошує на важливості «дискурсів-«свідчень» всіх тих, хто пережив, страждав або став жертвою, щоб «побачити» і «почути» трагедію. Саме з моменту написаного-виголошеного свідчення, незалежно від того, належить воно окремому індивіду чи групі людей, чи набуває форм художнього твору, розпочинається робота суспільства 3 наслідками свого травматичного досвіду. (Фелман Ш., 2009). Джеффрі Александер розширює зміст концепту «травмогенного характеру культури» на весь світ, особливо наголошуючи на чутливості до теми насилля не-західних частин світу, у яких останнім часом і відбуваються найбільш катастрафічні події. (Александер Дж., 2013).

Виявляється, що досвід України - від Майдану до анексії Криму та війни на Донбасі суголосний світовій історії початку XXI століття загалом. Він висвітлює загрозливі конфлікти уже в новітню еру людства. Тим більше, що у медіалізованому світі є унікальна можливість «...викликати відчуття одночасності історичного досвіду», «відчуття співпереживання досвіду» у різних народів, суспільств і категорій населення, що надає змогу сформуватись особливому типу спільної, соціальної автобіографічної пам'яті про події» (Олик Дж., 2012: 55).

Звертаючись до 2019 року, зазначимо, що для українського суспільства після пережитих майданів, після останніх президентських виборів, напевно, найбільш характерним є «синдром наступного ранку». В історії України вкотре актуалізується проблема довіри і взаєморозуміння між громадянами, тобто постає можливість сповідувати спільні цінності як основу культура й ідентичності спільноти. Соціальна амбівалентність, як одночасна прихильність людей до протилежних, часом непоєднанних цінностей, характеризує перехідне суспільство.

Довга тінь минулого i, водночас, незворотність історичного поступу до свободи - це ті полюси напруження, які визначають шлях до формування оновленої української нації, вони сприятимуть об'єднанню заходу і сходу, півночі і півдня, минулого і теперішнього України. «Майдан, - на думку культуролога і політолога Тараса Возняка, - став вузькою шпариною, крізь яку ми можемо зазирнути у майбутнє.» (Т. Возняк, 2014: 90).

Ще одним фактором залежності і неможливості забути пережите є те неймовірне напруження духу, захоплююча атмосфера значущості того, що відбувається, адже саме це стало для багатьох «вершиною життя». Загалом, це стан будь-кого «надмірного» суб'єкта чи суб'єкта в жалобі, не здатного подолати меланхолійної залежності від пережитого чи закоханості. Саме ці полюси світовідчування трагічно поєднали в часі і просторі дві надмірні особистості, двох талановитих митців - Василя Співака, оперного співака, який полишив своє успішне творче життя в Парижі, щоб боротися і померти за Україну, і Леоніда Кантера, співавтора документального фільму про нього - «Міф». Така назва - це скорочене від «Мефістофель», це позивні героя - відсилання до улюбленого персонажа співака з опери «Фауст». Режисер Леонід Кантер у співаторстві з І. Ясним уник відвертої міфотворчості, надавши перевагу зворушливим роздумам про В.Сліпака, про природу жертв і воєн загалом. Це філософське, глибоко гуманістичне і багатогранне послання про максималістську особистість. «Міф» розпочинається і завершується тим, що паризькі діти у класі слухають, як їх учитель читає книгу Джані Радарі. Джельсоміно своїм чарівним голосом, якого не можна було не почути, зміг урятувати Країну брехунів, вигнавши правителя-самодержавця. Василь Сліпак загинув, а Україну... досі не врятовано. Його голос продовжує звучати, його чують... Однак життя здійснює свою трагічну рекурсію: на Донбасі триває війна, триває протистояння політиків, партій, людей... Тим часом 
на власноруч збудованому арт-хуторі Обирок ( так би мовити, ще на одному, вже українському «Неверленді») Леонід Кантер на 36-му році життя вчинив самогубство.

«Слухання» (listening), вслухання у свій історичний досвід та в історії про нього, про їх винятковість вимагає багатогранного реагування, комплексного осмислення, зокрема й мистецького, адже йдеться про досвід, що випробовує межі нашого розуміння.

Українське суспільством має ще усвідомити свої трагічні втрати, об’єднатись, щоб окрема особистість не потрапила в «...глухий кут нескінченної меланхолії, неможливості скорботи...», що виявляється у нав'язливій реактуалізації переживання, у втручанні минулого в теперішнє як вияві краху розрізнення часу. Таким чином, усвідомлення трагічного досвіду як своєрідної незагойної «рани» на культурній тканині суспільства важливе тому, що він має потужну інерцією, набуваючи «символічного розширення» (Александер Дж., 2012:102-103) й універсалізації, необхідних для його зрозуміння. Це призводить до порушення світу сенсів $\mathrm{i}$ смислів, що триває у часопросторі культури, транслюючись від покоління до покоління.

Як свого часу слово «Голокост» (з івриту «Shoа» - «катастрофа», «лихо») після показу однойменного серіалу на американському телебаченні (1978), так і слова «Чорнобиль», «Майдан» «війна на Донбасі», «анексія Криму» набули значення своєрідної метафори, вони не тільки виражають трагізм історичного досвіду українського народу, а й застерігають людство від загроз на шляху його подальшого культурного поступу. Отже, не тільки ми «вдивляємось» у наше минуле й теперішнє, а весь світ зважає на наш історичний досвід. Зрештою, в цьому й полягає зміна світових наративів в умовах «транскультурності» на початку XXI століття, коли Україна, з іï надзвичайно складним і полівекторним соціальним і культурним поступом, творить цілком унікальну, модель національного буття.

Висновки. Здійснивши аналітичний огляд трагічних подій в історії України протягом кінця XX - початку XXI століть, спираючись на міждисциплінарні дослідження концепту травми, на різні типи наративу про колективний травмуючий досвід, якого набуло українське суспільство на початку XXI століття, можна стверджувати, що вони суттєво впливають на культуротворчі процеси сучасності. Це надало можливість показати розвиток української культури цього періоду як відбиття тих глибинних травмуючих процесів, які визначають не лише іiі сьогодення, а й впливають на культурний поступ людства. Символічне розширення $\mathrm{i}$ співвіднесення досвіду українського народу із світовими трансгресивними процесами універсалізує його як такий, що має суттєве значення для глобального взаєморозуміння у світі, яке можливе тільки за умови здатності і готовності слухати і чути іншого.

\section{REFERENCES}

1. Alexander, J. (2013). The Meanings of Social Life: A Cultural Sociology [Smysly soczialnoj zhizni: kultursocziologiya], transl. from English. by G. K. Ol'khovikova; ed. D. Yu. Kurakina. Moscow: Praksis, 640 p. [in Russian].

2. Caruth, C. (1995). Trauma and Experience. In: Trauma: Explorations in Memory / ed. C. Caruth. Baltimore: Johns Hopkins University Press, pp. 3-12 [in English].

3. Einarsson, E. (2019). Chernobyl review: "Stunning and shattering in equal measure". Available at: https://www.gamesradar.com/chernobyl-hbo-review/ (Accessed: 19.01.2019). [in English].

4. Felman, Sh. (2009). Forms of Judicial Blindness, or The Evidence of Whast Cannot Be Seen [Slepota zakona i eyo formy', ili Svidetel'stvo nevidimogo]. In: Trauma: points [Travma: punkty], ed. S. Ushakin and E. Trubina. Moscow: Novoe literaturnoe obozrenie, pp. 516-561 [in Russian].

5. Hundorova, T. (2013). Transit Culture. Postcolonial Resentment [Tranzytna kultura. Symptomy postkolonialnoi travmy], articles and esses. Kyiv: Грані-T, 548 p. [in Ukrainian].

6. Luckhurst, R. (2008). The Trauma Question. New York: Routledge, 256 p. [in English].

7. Neal, A. G. (2005). National Trauma and Collective Memory: Extraordinary Events in the American Experience. Armonk; New York: Routledge; M. E. Sharpe, 272 p. [in English].

8. Olick, J. K. (2012). Figurastions of Memory: A Process-Relational Methodology illustrated in the German Case [Figuracziya pamyati: proczesso-relyaczionnaya metodologiya, illyustriruemaya na primere Germanii], transl. from English. by D. Khlevnyuk. In: Sociological Review [Socziologicheskoe obozrenie], vol. 11, 1, Moscow, pp. 40-74 [in Russian].

9. Plakhonin, A. (2019). That is Without Sin Among You [Khto z vas bez hrikha]. In: Day [Den], 112-113, June 27-28, p. 26 [in Ukrainian].

10. Ruth Leys. (2000). Trauma: A Genealogy. Chicago: University of Chicago Press, June 15, 328 p. [in English].

11. Voznyak, T. S. (2014). Maidan. (R)Evolution of Spirit: Arts and Cultural Studies Project [Maidan. (R)Evoliutsia dukhu: mystetsko-kulturolohichnyi proekt]. Kyiv: Nash format, 312 p. [in Ukrainian]. 